\title{
INTERDISCIPLINARY TAKE ON FOOD CONSUMPTION
}

\author{
Joanna Szwacka-Mokrzycka, PhD, Associate Professor ${ }^{1 *}$ \\ Faculty of Economic Sciences, Warsaw University of Life Sciences - SGGW \\ *https://orcid.org/0000-0001-9243-5404
}

\begin{abstract}
The main aim of this paper is to present economic and social aspects of food consumption studies. At the beginning, consumption is located among other sciences. Then, the methods used to study food consumption is presented, with particular attention paid to the method of econometric analysis and panel analysis. The last part of the paper presents the current state of studies in this area.
\end{abstract}

Key words: food consumption, methodology of consumption studies, panel models JEL codes: D1, D4, C23

\section{INTRODUCTION}

The interdisciplinary nature of approach to studies in consumption economics results from the multitude of areas it deals with, lying on the border of economics, social sciences, biological sciences and life sciences. The contribution of other scientific disciplines and branches is used in the formulation of theories and examination of processes occurring in various areas of consumption. What enjoys a special place and has special importance in the theory and application of consumption studies are "consumer behaviours", their determinants and the resulting decision-making process. The multifaceted nature of approaches to the description of causative agents of consumer behaviours determines the typology of consumer on the basis of social-and-psychological conditions. As a result of studies conducted in this area, "lifestyles" of consumers can be determined. What is significant for consumption studies is the assessment of the degree to which purchasing needs are met. Regarding consumption economics as a sub-discipline of economics results from the essence of the notion and the function the former serves in the economic system. The range of consumption covers both the direct act of fulfilment of a single need and human behaviours in the process of production, exchange and consumption of goods and services. From the macroeconomic point of view, consumption is treated as a phase in social reproduction responsible for the finalisation of the entire reproduction process. This multifaceted nature of approach to consumption determination indicates that it has a special place among economic sciences. At the same time, it should be noted that in the previous period (i.e. the period of the so-called classical economics - at the turn of the $18^{\text {th }}$ and $19^{\text {th }}$ centuries - and of pre-classical currents, such as mercantilism and physiocracy and Marxian economics) the consumption was placed in the margin of economic theories (Bywalec and Rudnicki, 1999). What

${ }^{1}$ Corresponding author: Nowoursynowska 166, 02-787 Warszawa, Poland, joanna_szwacka@sggw.pl 
had a strong impression on shaping the view of the role of consumption in centrally planned economy were the views of Lange, who stated that consumption was to be covered by out-of-economics sciences (Lange, 1978). The position of consumption in economic sciences started to be built in the 1960 s, first and foremost thanks to such outstanding scientists as Krzyżewski, Lipiński, Hodoly, Piasny and Pohorille. Consumption established its position among economic sciences in the 1970s. Special credit in this area is to be given to Hodoly, Szczepański and Pałaszewska-Reindl, Kusińska, Kos, Zielińska and others.

\section{PLACE OF CONSUMPTION AMONG OTHER SCIENCES}

At the beginning, consumption is defined in subjective and objective terms. The objective approach includes consumption of tangible goods and consumption of services. Consumption of tangible goods includes consumption of foodstuffs and consumption of manufactured articles. On the other hand, the consumption of services is divided into the consumption of tangible and intangible services. The subjective criterion of consumption refers to the individual (personal) approach or the collective approach (a household, a social group or the entire society).

Consumption is an interdisciplinary science which includes the achievements of many other disciplines: economics, sociology, psychology, anthropology, philosophy and management. In practice, the interdisciplinary nature of consumption can be seen in various approaches to its analysis. This is particularly well expressed in the analysis based on the economic and sociological approach, which is expressed by regarding consumption as a socioeconomic category (Bylok, 2013). The reasons for including consumption in the economic field are first and foremost needs and how and in what order they are satisfied (Maslow, 1990). From the point of view of the pondered economic context, what is important is how consumer needs are met.

Referring to the mechanism of market economy, the process of meeting needs unfolds, without doubt, through goods and services acquired during market exchange. This is expressed in the approach pro- posed by Bywalec and Rudnicki (2002), who pointed out that "consumption" is the act of fulfilling human needs by consuming tangible goods and services. It might be claimed that the process of consumption has strong cultural and social connotations. A wide reference to such a take on consumption can be found in Szczepański (1981), who draws attention to "taking consumption as a process of social reproduction and a sphere of social cooperation, which include [...] social life conditions - working conditions, level of life of people, consumption fund". On the other hand, the sociological approach to consumption pays attention to the social nature of human needs. This is about higher level needs, which appear as the society develops. What has a special impact on the emergence and development of these needs is the social surroundings and the used methods and forms of communication.

Referring the above to the role played by food in shaping interpersonal relations, attention needs to be drawn to strong social, economic, mental and cultural connotations of food. The cultural context is significant here, which is entails explaining relations between food systems and human behaviours. This is a subject covered by the anthropology of food, being a sub-discipline of cultural anthropology (Belasco, 2008). The sub-discipline attempts to locate food in the context of politics, ritual, production and distribution, sex and other spheres of social life. Food has been the main point of interest of anthropology, starting from the classification of dishes eaten by the studied communities (as part of the evolutionary paradigm) in order to determine the level of their development. That scientific discipline blossomed in the 1960s, which was related to the widening of the examination field with the analysis of structures connected with the preparation of meals and the manner of their consumption. The anthropology of food reached its culminating point towards the end of the 20th century as a result of the intensification of various consumption trends, especially activities accompanying the process of consumption covering gastronomy and entertainment services, TV and radio programmes and online blogs. The interdisciplinary approach to the anthropology of food is expressed by statements of social science researchers, including sociologists, 
anthropologists, philosophers and economists about the role and meaning of food in culture (Anthropology of food, n.d.).

As seen by sociology, consumption refers to consumerism resulting from secondary processing of prosaic, unchanging human needs and desires into the main drive of the society (Bauman, 2009). In the extended meaning, consumption society means a society that not only consumes, but also founds its existence on consumption (Baudrillard, 2006). Baudrillard pays special attention to the social dimension of consumption, which is expressed by communicating one's social status to others. The demonstrations of the attained social position is characteristic of late capitalist society. A feature of the functioning of the consumption society is its activity in shopping malls. This take clearly refers to the behaviours of societies of the $19^{\text {th }}$-century Paris, described as a large shopping mall with separated luxurious arcades (Benjamin, 2006). What is also pronounced in this take on consumption is regarding consumption through the prism of marketing, advertising in particular. The function of advertising to lead consumers to their own desires and needs and to indicate possibilities of satisfying them. The presented interpretation of consumers' needs and desires is also linked with the psychological approach here. The issue of the harmful effect of consumption on the human psyche is also tackled by philosophers, who point to the alienation and incapacitation of the consumer in the world of objects (Marks and Engels, 1966; Baudrillard, 2006). As pointed out by philosophers, fetish has a detrimental effect on the human psyche - taking the reins of the consumer's behaviour leads to the addiction of the individual to an object. The literature widely covers the subject of the consumer's identity in the late capitalist world, drawing attention to the imperfections of a consumption-based political system (Foucault, 1998). The contemporary incapacitation of the consumer is reinforced by the dictate of international corporations that run active advertising campaigns, which lead to a strong attachment of consumer to international brands (boiling down to the cult of these brands) (Klein, 2004).

The contemporary reference to the culture of consumption is a point of interest of cultural studies, inspired by currents of postmodernist philosophy.

\section{METHODOLOGY OF FOOD CONSUMPTION STUDIES}

Food consumption studies are interdisciplinary. Their range covers the economic and social as well as behavioural and marketing dimension. The paper focuses on the socioeconomic aspects, which are the fundamental area of studying the consumption sphere overall, including food. The most widespread direction of studies is the analysis of relations between the socioeconomic development of the country and changes occurring in the consumption sphere from the point of view of its volume and the consumption structure. In this area, quantitative studies have been carried out in Poland for years, aiming to determine the scope and direction of changes in food consumption as a result of increase in society's earnings (Zielińska, 1978; Szwacka-Salmonowicz, 2003; Kwasek, 2008, 2015; Szwacka-Mokrzycka, 2018).

\section{METHODOLOGY OF ECONOMETRIC STUDIES}

What is most frequently used in investigating the pace at which food consumption develops and at which its structure changes are the methods of econometric analysis (Welfe, 1977). They are quantitative and enable carrying out analyses in a wide scope, based on assessment measures. The measures are parameters estimated on the basis of various demand models as well as income elasticity coefficients, determining the strength of reaction of demand to changes in the level of consumers' earnings. It should be noted that econometric studies on transformation of the structure of food consumption have been carried out by many authors for years. To a large extent, this results from the specific nature of food, including the fact that it satisfies relatively homogenous needs of consumers, and from relative stability (predictability) of factors conditioning shopping processes. The specific, basic nature of food goods is also significant for forecasting the level of their saturation. From this point of view, many-year work targeting substantive analysis of processes concerning food consumption development were mostly related to the assessment of the adequacy of various econometric models for the description of empirical processes of food consumption development in Poland. What is the most adequate 
for the description of food consumption processes are functions of demand and asymptote determining the empirical level of saturation of consumption, assuming that consumers' income is growing without limitation (Zielińska, 1978).

As regards the food market, the patterns formulated by Keynes and Engel have been confirmed many a time, which concern the patterns visible in income spending, ones consisting in a change in general relations in consumption expenses and savings and in a change in the structure of expenses.

Studies verifying Engel's law are a point of interest to a lot of scientists and were reflected in numerous Polish and foreign papers (Zielińska, 1978; Deaton, 1998; Szwacka-Salmonowicz, 2003; Janoś-Kresło and Mróz, 2006; Kwasek, 2008, 2015; Szwacka-Mokrzycka, 2018). A specific expansion of Engel's law are Tornquist functions, presenting relations between consumers' expenses and income. They are the basis for approximation of Engel curves, assuming various forms depending on the type of the goods and services for which they are estimated.

\section{USE OF PANEL REGRESSION IN CONSUMPTION MODELLING}

At present, what is more and more often applied to study consumption are panel regression models, based on panel data obtained from Statistics Poland's statistics (Household Budget Survey).

Panel studies have a lot of advantages. They allow to carry out analysis in terms of both micro- and macro-consumption. Micro-panels are run in the context of households and macro-panels can include a given economy sector in their range. Panel studies enable increasing data sets, and so - expanding the analysis. They allow identifying causes for the studied phenomena and tracing their dynamics as well as controlling non-observable individual effects in regression models.

The notion "panel data" defines data sets containing information about the same objects (crosssectional information) in several periods (over time) (Maddala, 2001). Some authors (Dańska-Borsiak, 2009) regard panel data as a special type of time cross-section data. In this case the number of periods
$T$ is markedly lower than the number of objects $n$. Literature studies (Baltagi, 2005) confirm the edge of analyses carried out on panel data over the analyses of sets of cross-sectional data or several sets of crosssectional data containing objects that do not repeat. The edge is the observation of entities over consecutive periods. Data analysis carried out this way allows reducing measurement errors and problems resulting from the omission of non-observable variables or variables correlated with the explanatory variable (Osińska, 2007). Carrying out such analyses allows to identify causes of some phenomena.

\section{STATE OF KNOWLEDGE ON FOOD CONSUMPTION STUDIES}

As already stated, what is most frequently used in investigating the pace at which food consumption develops and at which its structure changes are the methods of econometric analysis. The source of information for carrying out these studies were household budget data of Statistics Poland. At the first stage of studies, analysis covered years 2001-2009, which allowed grasping the dynamics of changes occurring in the structure of food needs of Polish households. Food needs in 2009 were compared and contrasted with food needs in 2001. The next stage of the studies involved assessing the level at which the food needs of Polish households were satisfied in years 2003-2015. The aim of the studies was to determine the direction and scale of changes occurring in consumption patterns of Poles in the first and second decades of the $21^{\text {st }}$ century.

On the basis of many-year results of econometric studies, Engel-Keynes pattern was verified. Changes occurring in patterns of food consumption were assessed from the point of view of both quantitative satisfaction of food needs and qualitative transformations. The latter are mostly the effect of changes in the consumer's awareness, which leads to the verification of the eating habits present so far and change in the structure of preferences. This is expressed by structural changes and increase in rationalisation of food consumption over the investigated years.

The carried out analysis of food needs of Polish households leads to the classification of three main directions of change. It is connected with the degree 
to which needs are satisfied, qualitative transformations and substitution processes within the analysed food groups (Szwacka-Salmonowicz, 2003; Szwacka-Mokrzycka 2018).

Panel models were used to model the consumption of selected foodstuffs in econometric terms. Years 2003, 2009 and 2015 were investigated. During the studies, data from a household budget survey were used (Szwacka-Mokrzycka, 2018). The analysed data form a balanced panel. An attempt was made to build all presented models for panel data, but during the studies it turned out that the correct models are the ones with constant unit effects. The following panels were separated in the analysed data set: for households of employees, pensioners and disability pensioners and for households in general in years 2003-2015. On the basis of the analysis of panel data for each of the three household groups, three categories of models were built: a model estimated with the classic least square method, a fixed effects model (FEM model) and random effects model (REM model). In total, 42 models were built for each household group. The next stage of panel studies was statistical verification, which allowed making the final decision as to what model to select.

Some of the selected product categories show individual effects. This can indicate a changing tendency in their consumption. Analysing the built models, one can observe significant differences in the consumption of the studied products between quintile groups; the disproportion is usually the most pronounced for two extreme groups. This means that consumption behaviours of Poles are significantly differentiated by the income level. In relative low income households, demand for food is relatively high. On the other hand, in relatively high income households, there is a low sensitivity of consumption to increase in income. The pattern that the level of food need satisfaction grows as income goes up was confirmed. There is also high differentiation in the shaping of the consumption of food products depending on product categories. In relation to absolutely essential products, buyers showed a relatively weak reaction to change in income, which was expressed by increase in consumption. On the other hand, the demand for products with higher processing degree is still relatively high.

\section{CONCLUSIONS}

Most frequently, methods of econometric analysis are employed to investigate the pace at which food consumption develops and at which its structure changes. The application of the logarithmic and hyperbolic model to the hierarchisation and assessment of the direction of changes in food needs in years 1996-2015 proved to be adequate. At the same, it was confirmed that the coefficients of income elasticity of demand are the basic measurements for assessment of the level at which food needs are satisfied, the scope of qualitative changes and the degree of substitution in individual product categories. Those studies were the continuation of the work carried out by the author in years 1996-2001.

At present, what is more and more often applied to study food consumption are panel regression models, based on panel data obtained from Statistics Poland's statistics. They are a new solution in consumption modelling developed by the author for the first time for the purposes of the food market. Panel models were used to model the consumption of selected foodstuffs in econometric terms.

\section{REFERENCES}

1. Anthropology of food (n.d.). Retrieved from: http://aof. revues.org [Access 09.12.2017].

2. Baltagi, B.H. (2005). Econometric Analysis of Panel Data. John Wiley and Sons, Chichester.

3. Baudrillard, J. (2006). Społeczeństwo konsumpcyjne. Jego mity i struktury [Consumer society. His myths and structures]. Trans. S. Królak. Wydawnictwo Sic, Warszawa.

4. Bauman, Z. (2009). Konsumowanie życia [Consuming life]. Wydawnictwo Uniwersytetu Jagiellońskiego, Kraków.

5. Belasco, W.J. (2008). Food: the key concepts. Berg, Oxford - New York.

6. Benjamin, W. (2006). Pasaże [Passages]. Trans. I. Kania. Wydawnictwo Literackie, Kraków.

7. Bylok, F. (2013). Konsumpcja, konsument i społeczeństwo konsumpcyjne we współczesnym świecie [Consumption, consumer and consumer society in the modern world]. Wydawnictwo Naukowe Śląsk, Katowice.

8. Bywalec, Cz., Rudnicki, I. (2002). Konsumpcja [Consumption]. PWE, Warszawa. 
9. Dańska-Borsiak, B. (2009). Zastosowania panelowych modeli dynamicznych w badaniach mikroekonomicznych i makroekonomicznych [Dynamic panel data models in microeconomic and macroeconomic research]. Przegląd Statystyczny, 56 (2), pp. 25-41.

10. Deaton, A. (1998). The analysis of household survey: a microeconometric approach to development policy. Johns Hopkins University Press, Baltimore MA.

11. Foucault, M. (1998). Trzeba bronić społeczeństwa: Wykłady w College de France [Society Must Be Defended: Lectures at the Collčge de France]. Polish translation M. Kowalska. Wydawnictwo KR, Warszawa.

12. Janoś-Kresło, M., Mróz, B. (2006). Konsument i konsumpcja w gospodarce rynkowej [Consumer and consumption in a market economy]. Oficyna Wydawnicza SGH, Warszawa.

13. Klein, N. (2004). No Logo. Trans. H. Pustuła. Świat Literacki, Izabelin.

14. Kwasek, M. (2008). Dochodowa elastyczność popytu na żywność [Income elasticity of demand for food]. Wiadomości Statystyczne, 5, pp. 39-51.

15. Kwasek, M. (ed.) (2015). Z badań nad rolnictwem społecznie zrównoważonym [From research on socially sustainable agriculture] (33). Analiza bezpieczeństwa żywnościowego Polski. Monografie Programu Wieloletniego, 19. IERiGŻ-PIB, Warszawa.

16. Lange, O. (1978). Ekonomia polityczna [Political economy]. Vols. I, II. PWN, Warszawa.

17. Maddala, G.S. (2001). Introduction to Econometrics, John Wiley and Sons Ltd, Chichester.

18. Marks, K., Engels, F. (1996). Przyczynek do krytyki ekonomii politycznej [A contribution to the criticism of political economy]. Trans. E. Lipiński. Wydawnictwo KiW, Warszawa.

19. Maslow, A.M. (1990). Motywacja i osobowość [Motivation and personality]. Instytut Wydawniczy PAX, Warszawa.

20. Osińska, M. (ed.). (2007). Ekonometria współczesna [Contemporary econometrics]. Druk-Intro, Inowrocław - Torun.

21. Szczepański, J. (1981). Konsumpcja a rozwój człowieka. Wstęp do antropologicznej teorii konsumpcji [Consumption and human development. Introduction to anthropological consumption theory]. PWE, Warszawa.

22. Szwacka-Mokrzycka, J. (2018). Paradygmaty rozwoju konsumpcji żywności w Polsce [Paradigms of food consumption development in Poland]. Wydawnictwo Naukowe PWN, Warszawa.

23. Szwacka-Salmonowicz, J. (2003). Zmiany zachowań nabywców jako determinanta kształtowania strategii segmentacyjnych przedsiębiorstw przemysłu spożywczego w Polsce [Changes in buyer behaviour as a determinant in shaping segmentation strategies of the food industry enterprises in Poland]. Wydawnictwo SGGW, Warszawa.

24. Welfe, W. (1977). Ekonometria stosowana [Applied econometrics]. PWE, Warszawa.

25. Zielińska, Z. (1978). Współczynniki elastyczności dochodowej jako mierniki przemian w strukturze spożycia żywności w Polsce [Income elasticity coefficients as measures of changes in the structure of food consumption in Poland]. Handel Wewnętrzny, 5. 